\title{
SYSTEM CHANGE AGENTS: A PROFILE OF POLICY-FOCUSED GRANTMAKING FOUNDATION ENGAGEMENT IN PUBLIC POLICY
}

\author{
Peter R. Elson \\ Mount Royal University \& University of Victoria \\ Sarah Hall \\ McGill University
}

\begin{abstract}
This study profiles the engagement of policy-focused Canadian grantmaking foundations in public policy. Policy-focused foundations now realize that downstream community issues are not isolated from upstream policy and regulatory practices. Foundation policy engagement has been measured across five policy streams: research and issue identification; policy entrepreneurship and convening; advocacy; implementation; and evaluation and impact. Themes emerging from this research include: 1) a migration from program into policy engagement; 2) the utilization of multiple soft and hard policy tools; 3) simultaneous engagement across multiple policy streams; 4) engagement with both systems and agents; 5) engagement in policy implementation; and 6) a long-term commitment to a focused policy issue. This research opens the door to a rich analysis of public policy engagement by grantmaking foundations.
\end{abstract}

\section{RÉSUMÉ}

Cette étude décrit la participation aux politiques publiques de la part de fondations subventionnaires canadiennes axées sur les politiques. On reconnaît de plus en plus que les questions communautaires en aval ne sont pas isolées des pratiques reliées aux politiques et aux réglementations en amont. Dans ce contexte, la participation a été mesurée par rapport à cinq domaines: la recherche sur les politiques et le repérage de problèmes; l'entreprenariat et la convocation en matière de politiques; la défense des politiques; l'application des politiques; l'évaluation et l'impact des politiques. Les thèmes soulevés dans cette recherche comprennent: 1) le passage d'une participation aux programmes vers une participation aux politiques; 2) l'utilisation de multiples instruments politiques durs et doux; 3) une participation simultanée dans divers champs politiques; 4) une participation à la fois avec des systèmes et des agents; 5) une participation dans l'application de politiques; 6) une participation à long terme vis-à-vis de problèmes politiques spécifiques. Cette recherche ouvre la voie à une riche analyse de la participation aux politiques publiques de la part de fondations subventionnaires.

KEYWORDS / MOTS CLÉS: Grant-making foundations; Public policy; Canada / Fondations subventionnaires; Politique publique; Canada 


\section{Elson \& Hall (2016)}

\section{INTRODUCTION}

If we are really interested in transformational change and systemic change then we can't

bypass the public policy lever. Whether government or school boards-public policy broadly defined-we have to go to where policy is being made in order to change things.

-Foundation 6

The very fact that foundations can operate independently of political parties, government, and public administration creates opportunities for the support of causes that mainstream politics will either bypass or be reluctant to embrace (Anheier, 2005). Others observers have been even more explicit: "The privacy of foundations is a privilege awarded to them because of their contribution to society, not an excuse to ignore the responsibilities of citizenship in a democratic society" (Mcllnay, 1998, p. 101).

Within an ever-evolving philanthropic sector, Canadian grantmaking foundations are well positioned to effect societal change through innovative tools and strategies and a wide range of roles available to them. This includes the autonomy of foundations to address issues that are either controversial or peripheral to government policy (Frumkin, 2006). While program activities, both direct and indirect, naturally dominate the grantmaking landscape, there is a growing realization by public and private foundations alike that downstream community issues are not isolated from upstream policy and regulatory practices. For example, there is little doubt that policies in which foundations have played a part, such as the Registered Disability Savings Plan, carbon taxes, early childhood education, and social procurement policies, have made a contribution to the quality of life of Canadians.

Grantmaking foundations trying to leverage their influence and improve their impact are increasingly being urged by foundation sector leaders to embrace advocacy and public policy grantmaking as a way to substantially enhance their results and advance their missions (Cave, 2016; Northcott, 2016; Philanthropic Foundations Canada, 2016). In fact, public policy grantmaking has been described as "one of the most powerful tools available to foundations for creating real change" (Alliance for Justice, 2004, p. 1; see also Coffman, 2008). For example, the Margaret \& Wallace McCain Family Foundation and the Atkinson Charitable Foundation were both instrumental in supporting the movement for early childhood education in Ontario (Turgeon, 2014).

The purpose of this article is twofold: to present a theoretical framework that can speak to the question of the ways in which Canadian grantmaking foundations engage in public policy, and to present the findings of indepth interviews with 13 of Canada's policy-focused grantmaking foundations with an active and sustained engagement in public policy. The article concludes with some preliminary observations about the state, scope, and impact of these policy activities. To do this, it draws on academic literature, foundation websites, reports, and in-depth interviews with policy-focused Canadian grantmaking foundations that are actively engaged in public policy.

As this article will demonstrate, there is considerably more to the formulation and implementation of public policy than items that reach the front pages of newspapers or the back rooms of legislatures. There is, we posit, a wide range of roles that grantmaking foundations can play in the public policy process, from engaging or funding primary research to monitoring policy implementation and community impact. While the Canada Revenue Agency stipulates that as registered charities, 10 percent of a foundation's resources can be directed toward political activities, only a fraction of public policy activities can be considered political (Canada Revenue Agency, 2003). For example, under present law, a charity is not restricted from providing information and expressing its views in briefs to government to change laws or policies. Charitable activities (not advocacy) also include 
distributing research to politicians or presenting a research report to a standing committee, and organizing or participating in policy development working groups (Carter \& Man, 2010).

\section{OVERVIEW OF CANADIAN GRANTMAKING FOUNDATIONS}

Legally, registered charitable foundations in Canada include private foundations (e.g., the Lucie et André Chagnon Foundation, McConnell Foundation, Maytree Foundation, Suncor Foundation) and public foundations (e.g., United Ways, community foundations). ${ }^{1}$ These two designations are split roughly fifty-fifty between the two categories and are distinguished from each other by their source of capital as well as the degree of independence that exists between foundation directors (Philanthropic Foundations Canada, 2015) (see Figure 1). Apart from their status as public or private foundations, foundations can, for analytical purposes, be subdivided into several types. As profiled in Table 1 , public and private foundations share several characteristics, and are differentiated by the arms-length separation of members of the foundation board. This arms-length separation must be more than fifty percent in public foundations and may be less than fifty percent in private foundations ( Canada Revenue Agency, 2017). These types include family foundations, independent foundations, corporate foundations, and community foundations. The focus here is on both private and public foundations and their engagement in the public policy process.

\section{Figure 1: Overview of the foundation sector OVERVIEW OF THEFOUNDATION SECTOR NUMBEROF CHARITIES 86,592(2015)}

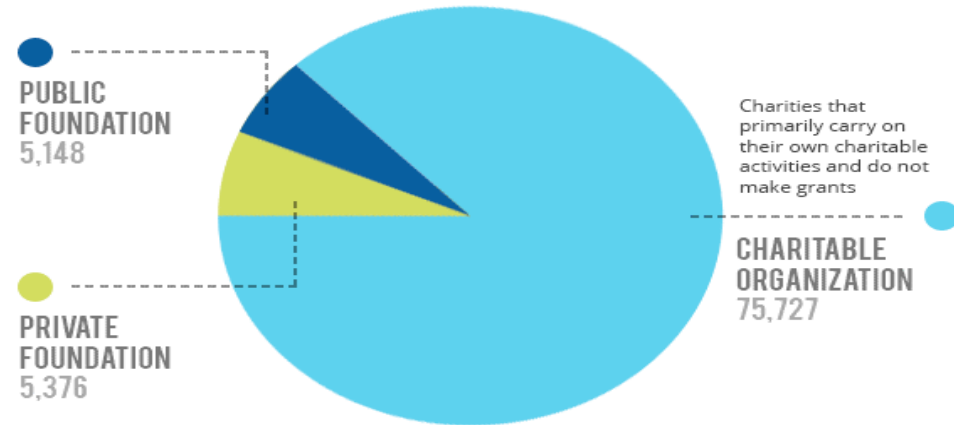

Source: Canada Revenue Agency, 2016; Philanthropic Foundations Canada, 2015

Table 1: Private and public foundations

\begin{tabular}{|l|l|}
\hline Private Foundation & Public Foundation \\
\hline Is established as a corporation or a trust & Is established as a corporation or a trust \\
\hline Has exclusively charitable purposes & Has exclusively charitable purposes \\
\hline $\begin{array}{l}\text { Carries on its own charitable activities and/or funds other } \\
\text { qualified donees (e.g., registered charities) }\end{array}$ & $\begin{array}{l}\text { Generally gives more than } 50 \text { percent of its } \\
\text { income annually to other qualified donees (e.g., } \\
\text { registered charities), but it may carry out some of } \\
\text { its own charitable activities }\end{array}$ \\
\hline $\begin{array}{l}\text { May have 50 percent or more of its governing officials not at } \\
\text { arm's length with each other }\end{array}$ & $\begin{array}{l}\text { More than } 50 \text { percent of its governing officials } \\
\text { must be at arm's length with each other }\end{array}$ \\
\hline $\begin{array}{l}\text { Generally receives the majority of its funding from a donor or a } \\
\text { group of donors that are not at arm's length }\end{array}$ & $\begin{array}{l}\text { Generally receives its funding from a variety of } \\
\text { arm's length donors }\end{array}$ \\
\hline $\begin{array}{l}\text { Its income cannot be used for the personal benefit of any of } \\
\text { its members, shareholders, or governing officials }\end{array}$ & $\begin{array}{l}\text { Its income cannot be used for the personal benefit } \\
\text { of any of its members, shareholders, or governing } \\
\text { officials }\end{array}$ \\
\hline
\end{tabular}




\section{Elson \& Hall (2016)}

Legally, grantmaking foundations in Canada include private foundations (e.g., family foundations, corporate foundations, faith-based foundations) and public foundations (e.g., United Ways, community foundations). These two designations are split roughly fifty-fifty between the two categories and are distinguished from each other by their source of capital as well as the degree of independence that exists between foundation directors (Imagine Canada \& Philanthropic Foundations Canada, 2014). Apart from their legal status as public or private, foundations can be subdivided into several types, including primarily family foundations, faith-based foundations, corporate foundations, and community foundations. The focus here is on both private and public foundations and their engagement in the public policy process.

Existing research literature reviewed to date has revealed few references specific to the Canadian context. There are some published case studies (Barata \& Murphy, 2011; Turgeon, 2014), and numerous reports, but little systematic research. The lack of any systematic exploration of Canadian foundations in the policy process is itself revealing and certainly speaks to the potential value of this research. There is, it seems, a chronic lack of information regarding either the collective or the individual impact of grantmaking foundations on public policy.

\section{THEORETICAL FRAMEWORK}

Drawing on and blending two distinct models of policy analysis frame this article. The first is John Kingdon's (1995) "Three Stream" model of policy development and the second is Paul Sabatier and Daniel Mazmanian's (1979) Advocacy Coalition Framework, which focuses on policy implementation. In Table 2, the first three columns reflect Kingdon's policy development framework, and the last two address phases in policy implementation.

\section{Table 2: Policy engagement framework}

\begin{tabular}{|l|l|l|l|l|}
\hline Problem/Issue Stream & Policy Stream & Political Stream & $\begin{array}{l}\text { Implementation } \\
\text { Stream }\end{array}$ & Impact Stream \\
\hline $\begin{array}{l}\text { Policy research and issue } \\
\text { identification }\end{array}$ & $\begin{array}{l}\text { Policy entrepreneurship } \\
\text { and convening }\end{array}$ & $\begin{array}{l}\text { Policy advocacy and } \\
\text { issue resolution, } \\
\text { political action }\end{array}$ & $\begin{array}{l}\text { Policy implementation } \\
\text { monitoring and } \\
\text { reinforcement }\end{array}$ & $\begin{array}{l}\text { Policy } \\
\text { evaluation, } \\
\text { impact, and } \\
\text { renewal }\end{array}$ \\
\hline
\end{tabular}

Source: Kingdon, 1995; Sabatier \& Mazmanian, 1979

It should be noted that while this model is based on different streams/stages in policy development, from initial issue identification to policy implementation and monitoring, these streams/stages overlap, and policy development is not a linear process. Additionally, we expect to find that foundations are more involved in the first two streams. Finally, the goal here is to list examples from foundations for each of these different stages, but in many cases, a foundation's activities may fit into more than one of these streams (e.g., policy research and implementation).

\section{A five-stream model of policy engagement}

John Kingdon's (1995) "multiple streams" approach to framing policy development provides a means to explore the interrelationship of three "largely independent streams": problems, policies, and politics (see Table 2). The dynamic associated with these three streams, and the extent to which they are synergistically linked at the point when a policy window opens, determines whether advocates or policy entrepreneurs are in a position to press their positions and to succeed in effecting change (Kingdon, 1995). 


\section{Elson \& Hall (2016)}

The Problem Stream. The problem stream addresses the issue of why and how particular problems come to occupy the policy agenda. Included here are focusing events such as crises and disasters, feedback from current program operations, and the availability of indicator data.

Foundations have made a significant contribution in supporting community groups, academic researchers, and others in identifying the nature, scope, and extent of societal issues. Examples of such issues include child poverty, toxic soil, housing for single mothers, First Nations education, food security, social justice, and environmental and climate change impact. Producing sound statistical evidence regarding the extent of a problem helps to legitimize it as a "real" issue that warrants further attention by communities or policymakers, while human stories concerning the impact of such issues are equally important for balancing the statistical narrative. Having the right data is only the first step, albeit an important one. It is the interpretation of this data, not the statistics themselves (Kendall, 2000), and their relationship to existing or pending policy and political developments that will ultimately determine their policy impact (Kingdon, 1995).

The Policy Stream. The policy stream, in which policy alternatives are generated and championed by advocates, has been likened by Kingdon (1995) to a policy primordial soup in which a variety of combinations and permutations of ideas float around until the right combination of 1) technical feasibility, 2) congruence with community values, and 3) anticipation of future constraints, is reached. Some of these policy streams are predictable, such as budget consultations, a pending throne speech, or an election cycle, but they can also be triggered by media attention to an issue (e.g., outstanding health and support payments to thalidomide survivors) (Chase \& Peritz, 2015).

This stream often features the work of "policy entrepreneurs": those who work to propose a particular policy option and advocate for its adoption. A proposed carbon tax, zoning bylaw changes, the preservation of green space, equitable and affordable access to sports, housing, and healthy foods are a few areas where several policy options, incremental or otherwise, can be under consideration at any given time. Any policy option, or steps to support its development, including convening groups, is considered a charitable activity as long as the position is reasoned and takes alternative options into account. If the decision-makers are also considering alternative solutions, then analyzing the alternatives is an important contribution to any debate.

The Political Stream. The political stream, independent of problem recognition or policy proposals, flows with its own dynamics and rules. Pending retirements, leadership changes, provincial and/or federal elections, and external socioeconomic pressures can all foster a political climate that is conducive to change or retrenchment (Kingdon, 1995). However, in a broader context, most of the factors that structure relationships in civil society are, and will likely continue to be, determined by historical and socio-cultural factors and the political dynamic within individual countries (Deakin, 2001). This speaks to the complex challenges associated with sustained policy change.

While the political stream is only one of five policy development and implementation stages outlined here, it is no doubt the most contentious. Political activity 2 issues arise because a foundation or charity can be challenged not only for what it says, but also how it says it and how much it says. As outlined by charity lawyer Terry Carter (Carter \& Rains, 2015) in a recent paper on separating fact from fiction regarding political activity by charities:

Despite the stated importance of charities needing to be part of public policy debate in Canada, the federal government's unjustified allegations in recent years about charities purportedly misusing their statutory right to participate in political activities, fewer charities 


\section{Elson \& Hall (2016)}

are prepared to enter the risky arena of political activities. This is a regrettable development notwithstanding recent efforts at providing educational resources about what registered charities can do with regard to political activities. (p. 8)

Engagement in political activities is absolutely legal and necessary at points in the public policy process. That is not to diminish the advocacy "chill" that has descended on foundations since the 2012 federal budget with $\$ 13.4$ million allocated to auditing charities (White, 2014). Yet foundations, more than any other registered charity, are independent of government favours and funding. As noted above, foundations, within their 10 percent allowance, ${ }^{3}$ are able to engage in political activities. Not only are foundations able to engage in political activities, but it is important to people and communities in need and other registered charities that they do so.

The Implementation Stream. The policy implementation stream is the extension of the "Three Streams" model into the Advocacy Coalition Framework (ACF) first introduced by Paul Sabatier and Daniel Mazmanian in 1979 (Sabatier \& Mazmanian, 1979). While beyond the scope of this article, the ACF provides the opportunity to address the following four policy implementation issues: 1) the extent to which the actions of implementing officials and target groups are consistent with the objectives and procedures outlined in the policy decision; 2) the extent to which policy objectives were attained; 3 ) the principal factors affecting policy outcomes and impacts; and 4) how the policy was, or was not, reformulated. In addition, the ACF provides a conceptual framework to address policy implementation issues within a broader socioeconomic context.

According to Sabatier and Mazmanian (1979), the crucial role of implementation analysis is to identify the variables that affect the achievement of the policy objectives throughout the entire process. These variables can be divided into three broad categories: 1) the material variables associated with the problem(s) being addressed; 2) the structural dimensions that influence the implementation process; and 3) the net effect of a variety of contextual variables to support the policy (emphasis added). These three independent variables are applied by Sabatier and Mazmanian (1979) to five stages of policy implementation. They have been consolidated across two streams in this expanded policy stream model, namely policy implementation or output and policy impact.

The Impact Stream. Beyond the material and structural aspect of policy implementation, a policy needs a periodic political boost to maintain its visibility and relevance in a changing socioeconomic climate. Policy objectives should not be undermined by the emergence of conflicting public policies. Further, changes in the resources and attitudes of external stakeholders play a role (Mazmanian \& Sabatier, 1983). Strong intermediary organizations need the membership, resources, and expertise to position themselves as legitimate and necessary participants in the policy implementation process.

Careful and ongoing monitoring of policy impact is critical to ensuring that policies are implemented as intended, unforeseen consequences are identified and addressed, and policy modifications are made in line with contextual changes to ensure ongoing compliance and implementation. Foundations can play an important role in supporting the independent and ongoing monitoring of successful policy implementation. This monitoring can be an important indicator of adequate funding levels, statutory compliance, bureaucratic consistency, political support, and sustained problem resolution. Examples include monitoring regulatory compliance and sustained budget and staffing allocations. 


\section{Elson \& Hall (2016)}

\section{METHODOLOGY}

The operational definition of policy used here draws on the work of Eugene Meehan (1985), namely that "policy is an actor's (institutional or individual) guide to the conduct of action, particularly collective action" (p. 293). Within this contextual definition, there is the expectation that the actor has the capacity to produce change, to project future outcomes, to establish indicators of that change, to select a preferred outcome among available options, to initiate a plan of action, to establish a monitoring and feedback/adjustment system, and has the capacity to operationalize the foregoing (Meehan, 1985). The policy-focused grantmaking foundations selected for this study meet this operational definition.

Fourteen policy-focused Canadian grantmaking foundations were interviewed over a period of five months. The foundations were selected as policy-focused grantmaking foundations with an active and sustained engagement in public policy on the basis of the following criteria: 1) as independently recognized leaders in a particular field of public policy; 2) an active and sustained engagement in public policy for at least five years; and 3) a commitment of significant resources to achieving a clear and explicit public policy objective. In two cases multiple respondents were interviewed from the same foundation, and in all but one case the president or chief executive officer (CEO) was interviewed.

A semi-structured interview process was used and transcripts were subsequently analyzed to identify common themes and consolidate responses (Yin, 2009). Following the interview process it was determined that one foundation did not meet the selection criteria and was excluded from the subsequent analysis. The interview information was then triangulated with an analysis of foundation websites, annual reports, documented policy statements, and T3010 data (Canada Revenue Agency, 2016).

The selected grantmaking foundations are engaged in children and youth policy, including early childhood education policy (4); poverty, social justice, and economic inclusion policy (5); environmental policy (2); and health policy, including mental health policy (2).

Ten of the thirteen foundations are based in Central Canada and three in Western Canada. Ten of the thirteen are private foundations (five family-based and one faith-based); 4 and three are public (community) foundations. Collectively, the selected foundations hold $\$ 3.6$ billion (CDN) in assets and $\$ 98.7$ million was disbursed to grantees in 2014. The thirteen foundations have a total of 191 staff members, with an average of 14.7 and a range of 4 to 51 employees. The policy-focused grantmaking foundations collectively have 154 board members -126 who operate at arm's length from their foundation and 28 who do not. Arm's length foundation board members provide a wide range of independent knowledge, expertise, perspectives, and networks. The size of foundation boards ranged from 5 to 20 with an average of 11 board members (Canada Revenue Agency, 2016). The average age of these policy-focused foundations is 47.4 years and the age range is 16 to 74 years.

\section{FINDINGS}

The analysis of the research findings revealed six policy engagement themes: 1) a migration from program into policy engagement; 2) the utilization of multiple soft and hard policy tools; 3) simultaneous engagement across multiple policy streams; 4) engagement with both systems and agents; 5) engagement in policy implementation; and 6) a long-term policy commitment. These themes will each be addressed in turn. 


\section{Elson \& Hall (2016)}

\section{Migration into policy engagement}

While there were some exceptions where a grantmaking foundation was explicitly established with a mandate to engage in public policy, most foundations reported that they migrated into public policy from a growing appreciation of the limitations of a singular focus on program funding.

Here is a typical story relayed by respondents:

It would be fair to say that for most of the foundation's existence it has had no relationship to public policy, nor would it have considered it part of a charitable foundation's function.

The same respondent went on to say:

We started to see that a lot of the work that our grantees were doing on the ground ... had larger structural or systemic implications and in many cases the kind of work they were doing was either hampered, or not amplified as much as it could be, by the regulatory and policy frameworks they were working within. And the way we moved into the policy arena was to start to think about how to amplify what we saw on the ground.

And finally, following a strategic assessment of its role:

We saw the function of the foundation as serving as a conduit between grassroots innovation/grassroots work and the larger [policy] frameworks that sat over top of it. And if the foundation could move as a conduit moving up and down that system; and the way we could best do it was to try to pull innovation, perspective, practice, up from the ground, and put it into a sort of framework or analysis that would enable a more conducive environment at a policy/regulatory level for that work. (Foundation 2)

Without exception, the boards of all the policy-focused foundations interviewed were fully supportive of an active and progressive engagement in public policy. In at least two cases the current CEO was explicitly recruited because of his or her policy experience, in order to continue, build, or lead a transition into the public policy arena:

I think I would agree that part of the reason they hired me is that [policy] was something I was familiar with and so pretty much as I arrived the decision was that that would be a predominant focus for the organization-supporting policy research. (Foundation 12)

Another respondent explicitly called for board approval for a public policy orientation as a condition of their employment: "My one condition was that everyone on the board agreed that public policy would be the focus" (Foundation 5). Yet respondents were also clear that their foundations' investment in public policy was a way to support their program funding as well as achieve a difference in society that reached far beyond their particular sphere of influence. They also appear less interested in getting credit or profile from their work than they are in seeing a substantive policy change really take hold:

One of the tricky things of course is really around attribution, so I do recall some conversations we had several years ago, where we really wanted to see if there would be uptake around the [strategic approach to issue] with [proposed issue solution] being the 


\section{Elson \& Hall (2016)}

obvious one-but our conversations 3 or so years ago were that there's no way there's the political or public receptivity for a [proposed issue solution], we'll probably have to spend $3-5$ years just building awareness, doing the research, getting people comfortable with the idea, and at that point maybe there'd be a point for [proposed issue solution] to be part of the conversation. And now we have 4 provinces and $85 \%$ of the population living in areas that are committed to [proposed issue solution]. We don't take credit for that, but I think that we've contributed to the confidence and technical understanding and public awareness around the importance of these things. (Foundation 12)

Another foundation realized that the courts, not just policymakers, are a legitimate arena to engage in public policy: "The right to an [issue] in the Charter; it's a long drawn-out process. Litigation's not sexy, but we see that as underpinning a lot of the struggles that the [issue] sector is having" (Foundation 4).

This same respondent reported that the foundation divides its funding into two categories, one that provides a quick reactive capacity, and the other that is dedicated to "long-term, solutions-oriented" funding relationships (Foundation 4). These policy-focused grantmaking foundations also fund comprehensive evaluations of their funding partners (i.e., grant recipients) and build a research component into long-term policy initiatives. Foundations do not have a license to print money and they are acutely aware of their limited resources and the need to make their investments count: "They [referring to another foundation] have few resources, but [they] are really, really focused on what kind of impact they can have with their limited resources" (Foundation 1).

There is a clear realization by all those interviewed that engagement in public policy is a tremendous opportunity to make a significant, lasting impact with limited resources: "So if you can use the limited money that the foundation has to influence the way the government spends its money better, that would give you more leverage than anything else you could do" (Foundation 5).

\section{Utilization of both soft and hard policy tools}

Foundations in Canada are in a position to impact societal change and foster social innovation through a variety of tools. These tools include research, surveys, coalition building, direct action, legitimizing and supporting enabling strategies, public campaigns, and a range of funding and policies and practices that are directed at the general public, policy influencers, and decision makers (Coffman, 2008). Soft tools in this context have been identified as reputation, independence, and legitimacy. Hard tools include convening, funding, quiet diplomacy, and collective advocacy. Foundations take advantage of both hard and soft tools as they see fit across the full spectrum of policy-stream engagement.

\section{Reputation}

Policy-focused grantmaking foundations are growing more confident about prudently utilizing their reputation to achieve desired policy outcomes:

I would say a) we're very conscious of political capital and using it wisely but somewhat sparingly in that you don't want to be the flavour of the month, b) we know that on levering money and credibility that often by going first we'll give governments political cover and/or room to do things they might not otherwise do. (Foundation 9) 


\section{Elson \& Hall (2016)}

The same respondent used this example:

We were very involved in that [policy] process, and then stepped up publicly saying that in order to assist the [jurisdiction], which had fiscal constraints, that we provide a match up to $\$ 600,000$ over 3 years to help them get there more quickly. In doing that we knew that a) we'd make it easier for them financially, but b) we'd make it harder for them to not follow through. Unanimously.

And l'd say it wasn't lost on a lot of observers that it never would've been unanimous had we not stepped up to the plate. And it may not have carried. So we're conscious that there are ways in which our reputation and some money can really affect the attitude and willingness to step up by others. (Foundation 9)

\section{Independence}

Policy engagement was typically crafted creatively, taking the full advantage of the degree of independence foundations enjoy:

You're entirely independent in a way that very few institutions and organizations are. And because of that independence - it's advantageous strategically and tactically—but it also provides you with a unique position at these various tables and you're accorded a certain [degree of] legitimacy [too]. (Foundation 2)

These policy-focused foundations are acutely aware that with this freedom comes responsibility.

One of the biggest tools and advantages of a private foundation is its independence. And that's huge. Government doesn't have that; organizations on the ground don't have that. Very few organizations in Canada have true independence and we do. And that makes a big difference. We have to use that well. (Foundation 7)

\section{Legitimacy}

Often the question of legitimacy came as a surprise:

It took me by surprise a little bit, how the perception from various sectors is that if a foundation is involved in an issue it is seen as kind of benign and positive and constructive. The fact that we're given that kind of social license as a sector surprised me. I don't think there's something in the fact that because a foundation is a foundation that means that you've earned that [legitimacy], and yet we seem to be given that. So I see that as an enormous benefit because it means that people will often come if you invite them. (Foundation 2)

Another respondent had this to say, aware that legitimacy is a contentious issue in other jurisdictions: "It's an interesting one to figure out if we do have that legitimacy, but we certainly think we have credibility and experience" (Foundation 6). 


\section{Elson \& Hall (2016)}

\section{Convening}

Convening activities are widespread across all policy-focused grantmaking foundations interviewed in this study. They convene stakeholders themselves and actively encourage their grant-holders to do the same. Due to their legitimacy and convening power, they are able to bring together groups who might not otherwise connect in an atmosphere of candor and confidentiality.

We have an initiative for engaging policymakers and we've done this for three years in a row. We convene senior provincial policymakers in [policy issue] for a day-long workshop and we present innovations that we think they could implement in their province to improve [policy issue]. What, we ask, are the interesting initiatives that can help them do their job better? We also realized that this was an incredible way to get some of our projects in front of these people, and to establish [better] relationships. And what we've done too is to get together a group of philanthropic organizations; so we invite the senior policymakers and we invite the philanthropic organizations. And we invite some speakers and we get the officials to participate as well. But that [initiative] was our big, overall policy engagement piece. (Foundation 11)

Foundations can create a unique opportunity for convening that is not available in government, and indeed is appreciated by policymakers.

And another tool we're using is the role that we can play as conveners. So we're now meeting with different provincial ministries, and many of them have an appetite to get together. Not the politicians, but the policymakers. There's quite a bit of demand for us convening them-bringing them together maybe once/year, once/18 months. Something a foundation can do that others can't, behind closed doors; it's about understanding who's doing what. (Foundation 1)

Foundations fund others to initiate a convening process, but they also engage in it themselves.

Grant recipient] also does their own convenings with their people, we also as a foundation independently do our own convenings, and a lot of ours are to help us understand what's going on and provide us with ideas so we've gathered together meetings that include former CEOs and deputy ministers, and others .... (Foundation 12)

\section{Funding}

These policy-focused foundations fund a variety of initiatives that build a vertical integration of policy initiatives. Local groups are supported to advance policy changes at a community level while, at the same time, provincial or national research campaigns receive support and lessons from one level are transferred to another.

We are among the funders of population-wide type of data collection and studies like [name] a longitudinal study on the development of [issue group], and we are funding a number of other population-wide surveys and studies. We also support an observatory on [issue group] that brings together various data on the state of [issue group] in [province] and the environments in which they grow and we're going to use that as a starting point for dialogue with a number of stakeholders and the population on policy related issues. (Foundation 1) 


\section{Elson \& Hall (2016)}

Funding in the public policy arena is not without challenges:

We don't have an awful lot of money. But we do have a really strong board and staff and an organizational culture that is comfortable with risk and ambiguity. And [we are] able to move quite quickly. We see ourselves being most effective at the front-end of issues. (Foundation 1)

There are some foundation boards that struggle to differentiate between support for public policy engagement and the policy issue itself:

I've tried to communicate to the board that just because we've funded a report doesn't mean we agree with the content. We're funding their right to participate in a political process.... (Foundation 3)

Another respondent was even more specific about their funding commitment to policy engagement:

I'd say that probably $80 \%$ of all of the funding -a little over $\$ 2$ million/year in direct grants-have [sic] gone toward public policy-oriented activities. And the classic example would be our funding of [policy issue], because it's a high profile national program that has an overall impact over tens of thousands of people for an unlimited amount of time. So our investment of $\$ 700,000$ over a 3-4 year period, which now shows that there's well over $\$ 2$ billion set aside by people who want to help [policy issue], would suggest that it's had a pretty significant impact.

We're not saying in any way-and we're not naïve enough to think-that because we funded these things they happened. On that particular example-notwithstanding the good work that the work did, were it not for [politician] and his championing of it, we'd still be talking about it. (Foundation 5)

\section{Quiet diplomacy}

The visible features of advocacy and policy engagement receive a lot of attention, often out of proportion to their impact. Virtually all of the policy-focused grantmaking foundations interviewed for this study engage in quiet diplomacy. Some of their quiet diplomacy comes in the form of convening activities, often under Chatham House Rule (Chatham House, 2017), but where they have ready access to political leaders; they are not shy about making contact. More often though, they are fully aware that policy change will require a commitment that outlasts the tenure of any given politician and that the support of policymakers is critical.

I think we really pick and choose how often we're out in front, deputing publicly, vs. how often we support others to do this, but we are quietly inside government. (Foundation 13)

a lot of research that's been funded over the years (we work in the area of [policy issue]) and we have been a really quiet foundation, working behind the curtain. (Foundation 6 ) 


\section{Elson \& Hall (2016)}

\section{Collective advocacy}

While all of these policy-focused foundations fund grassroots activists and coalitions, there is a new confidence among these policy-focused grantmaking foundations themselves that manifests itself in very public support for a policy issue. Here are two examples:

1. The first is an open letter published on March 11, 2015, in Le Devoir newspaper. Entitled, "Let's Not Lose Sight of the Impact of the Reforms on Social Inequality (Fondation Lucie et André Chagnon, 2015), it was signed by the directors of nine Québec-based foundations: the Fondation Béati, the Fondation BerthiaumeDu Tremblay, the Foundation of the YMCAs of Québec, the Fondation Dufresne et Gauthier, the Lea Roback Foundation, the Lucie et André Chagnon Foundation, the Fondation Solstice, the Women's $Y$ Foundation, and the J.W. McConnell Family Foundation. The open letter in Le Devoir called for greater awareness by the provincial government of the impact of a proposed provincial austerity program on economic inequality. This public policy engagement was unprecedented and closely watched by other foundations across Canada.

2. The second example followed shortly afterward. Buoyed by the release of the first open letter in Québec, a second open letter was penned by eight foundations focusing on early childhood education. Entitled, "A Smart Investment in Our Future" (Early Child Development Funders Working Group, 2015), it was released on June 30, 2015, to the media and signed by the Muttart Foundation, the Lucie et Andre Chagnon Foundation, the J.W. McConnell Family Foundation, the Lawson Foundation, the Jimmy Pratt Foundation, the Lyle S. Hallman Foundation, the Margaret \& Wallace McCain Family Foundation, and the Atkinson Foundation.

According to interview respondents, this degree of public collaboration is the direct result of ongoing working relationships and the subsequent level of trust that has been built over a considerable period of time. There is also a need for alignment with not only the policy issue itself, but also with the intervention strategy and timing. This is not always the case. One foundation finds that policy partners do not always have the same degree of flexibility and responsiveness, and another withdrew from a long-term collaboration with a provincial government because it felt its policy objectives were being compromised.

This is how one foundation approaches its decision to go public:

We have a process that we go through, a screening that's called eyes wide open that looks at the risks involved in staking a public position, and what are the stakes of doing nothing. And we're careful that we're not the flavour of the week, we don't do it every time there's a local controversy, but when they're significant issues that will affect the community, we've been fairly assertive. (Foundation 9)

In other cases foundations support external collective advocacy, providing the opportunity for indigenous and civic society leaders to have a voice. Respondents reported that this degree of community collaboration also helps the foundations to be more sensitive to the needs and aspirations of the communities in which they have a presence (Foundation 8). In the words of one respondent, "we often think of advocacy as confrontation but actually, advocacy starts with collaboration" (Foundation 1). 


\section{Elson \& Hall (2016)}

The appetite for collective advocacy and collaboration is growing:

I think collaboration is becoming more common in the Canadian foundation effort than it was. [There are more] opportunities and active interest than there used to be. [There is] a growing realization among foundations who are interested in social change that their ambitions and aspirations far outstrip their resources. If they want to have the kind of impact they're seeking, they need to think about partnerships, alliances, [and] collaborations. (Foundation 2)

\section{Simultaneous engagement across multiple policy streams}

These policy-focused grantmaking foundations operate from an activist rather than a theoretical perspective. While they certainly take advantage of theories that may inform their practice, there is a much stronger orientation toward creating continuous feedback loops and experimenting to see what works in their policy context.

That [funding partnership] created unlikely partnerships that ended up building out their reach to organizations they might not have worked with. [We have a] willingness to experiment. We make them a little uncomfortable, and we get right in there, and we really see ourselves and our role to actively engage in the work we're supporting. And to do whatever we can to ensure that they're reaching their full potential. (Foundation 4)

Rather than progressing in an orderly fashion through a policy development process, it is more likely that these policy-focused grantmaking foundations operate simultaneously across several policy streams. This, we posit, is because these policy-focused grantmaking foundations are addressing policy systems, and not a policy agenda in isolation of the systems in which policies either thrive or stagnate. These policy-focused foundations are as aware of plans and programs as they are of the processes that enable them to keep clarifying their intent and strengthening their connection with new people and new ideas. The result is an organization that is as "resilient and flexible as a spider's web" (Wheatley, 2006, p. 155).

Our board understood the importance of public policy because our vision at that time was to see government about policies, programs and measures favourable to the prevention of [issue]. It was a learning process for us to see that vision and to see how to make it happen. (Foundation 1)

This same respondent went on to say:

There's a huge transition with lots of unknowns and lots of tests. We're in a very testing type of phase. Moving targets and shifting ground. We're not blind, but we're on shifting ground. At the same time it's an exciting time. As much as change is disturbing, it's creating all kinds of opportunities. And it's true for policy engagement activities. (Foundation 1)

Another respondent confirmed this multi-strategy approach this way:

I would characterize us as very creative and innovative in how we work-I think we look for where there are bases and policy openings-a very deliberate reason why we're 


\section{Elson \& Hall (2016)}

working in [issue]-is because that's where the majority of new money in this country is. Government is spending money in this area. And we think that we should be asking: for every public infrastructure dollar we're spending, how are we building community? (Foundation 13)

These policy-focused grantmaking foundations see public policy engagement in the context of complex adaptive systems rather than systematic progress, which is reflected in the model outlined at the outset of this article (Stacey, 1995, 2007). In the words of one respondent, "We have purposefully built a robust and multidimensional public policy program around seeking better outcomes for [people with issue] "(Foundation 3). While they keep their eye focused on the public policy outcome, they realize that a complex interaction of systems, knowledge, skill, and opportunity each play a role.

\section{Engaging systems and agents}

Consistent with the theme of simultaneously engaging in multiple policy streams, foundations exercise their own agency as policy advocates and support others to do the same.

I'm hoping to encourage the philanthropic community to see this as an important issue, at the same time my partner [i.e., funding grantee] is hoping to influence other [issuerelated] agencies to become part of a cohesive response so they're all working together collectively to improve their chances of making real systems change. (Foundation 4)

In other cases the agent was not a coalition of organizations, but individual policy entrepreneurs:

But the most effective model for us was the [program]. [These funded individuals] are typically relationships that [Foundation 2] enters into often with a practitioner to write a very practical paper around an issue or a challenge or opportunity that we see in the sector where there's a way to create a bridge or transition between the kind of grassroots needs or practice, and policy innovation or change ... There are two important parts of this [program]: 1) The production of papers, not as abstract papers but as opportunities for action. 2) The other important part is that fellows then become policy resources for the sector more generally ... When we saw the impact that that relatively modest investment yielded, we broadened the program across all our program areas. (Foundation 2)

This foundation reflects a recommendation in social innovation literature that calls for support for people, particularly those with a strong and passionate sense of calling and an emphasis on changing the rules of interaction (Westley, Zimmerman, \& Patton, 2006).

These policy-focused grantmaking foundations are acutely aware of the systems in which they operate and the complex relationships that exist both within and between large systems (Waddell, Waddock, Cornell, Dentoni, McLachlan, \& Meszoely, 2015).

I think the foundation has had a very good history of being part of system influence, or trying to deploy some of its resources to address root causes. So it's not a new thing, it's an extension of a legacy of many years. (Foundation 10) 


\section{Elson \& Hall (2016)}

This perspective was echoed by another foundation:

Conceptually we've embraced the idea that you need to think about the long-term to solve complex issues. Where it's challenging for us is that we have to do that on spec/faith because we move into that space without long-term commitments from funders/donors. So we need to make sure we're not making commitments we can't live up to. We've had support from some long-term, major institutional funders that has helped ... but overall it's a very iterative and nuanced exercise. (Foundation 8)

\section{Engagement in policy implementation}

Policy-focused grantmaking foundations tend to be more engaged in the policy development process, but the research also revealed examples of their engagement in monitoring and policy implementation. A foundation may reduce its own commitment once a public policy has moved from the margins and garnered broader acceptance, support, and additional funding from other foundations and stakeholders.

This is a sentiment shared by many of the respondents:

We see our job as being early into areas and issues that require attention and resources. We're about enabling that issue to get some light and some people and ideas. But we're never going to be an operating funder, we've got no money and that's not where our real value is. The word catalyst is a good word. We're hoping we can catalyze issues early, and then create the connections, resources, etc. behind it to give it greater scale and weight where all sorts of other important actors [and foundations] are in that space. (Foundation 1)

At the same time, these policy-focused foundations see policy monitoring as a critical role and fund projects accordingly:

The [funded project] will be a systematic illustration of that. It will track very specific indicators over time, to do awareness-raising and dialogue on this. We also fund and use population-wide data that are related to our mission and approaches. (Foundation 1)

\section{Long-term policy commitment}

For these policy-focused grantmaking foundations, a long-term strategic partnership is the rule, not the exception. They are not shy about engaging in long-term funding and policy strategy to ensure the best chances that a policy shift occurs:

If we wanted to shift the parameters of how things are done-though not necessarily framed in terms of public policy-and want to bring to attention to various levels of government issues that we're passionate about, then we have to think in terms of a longer-term commitment, we have to shift how we do things, had to seek out partners that are prepared to go the distance with us. (Foundation 4) 


\section{Elson \& Hall (2016)}

These policy-focused grantmaking foundations are prepared to take decades, if necessary, to address deeply rooted societal issues and are aware of the resources, such as research and funding for networks. Here are two examples of the patience and perseverance required for long-term policy engagement:

So if you're not prepared to be there for the long term, the chances of success are much lower. So we've decided that's the approach we'll take so that's one thing-just showing up for work every day and keeping at it. "Relentless incrementalism"-we use that term. (Foundation 7)

We're not naïve, we know that this will take a lot of time. It's very incremental as you know. So I think the board understands that this isn't about changing things overnight, but it will take time, patience. (Foundation 6)

Two other features of a long-term policy commitment are focus and evaluation:

Focus, absolutely-you can't be a strong policy interlocutor on 15 issues, you just don't have the credibility, its [sic] 1 or 2 areas. (Foundation 5)

Because it's a long-term commitment we're making, a decade or more starting in [target location], we know that as we begin to scale the interventions (things like parental involvement, extracurricular support, etc.) that we need to be able to rigorously evaluate. (Foundation 9)

While not exhaustive, these policy-focused grantmaking foundations have demonstrated, in addition to the aforementioned themes, that a long-term commitment to a public policy agenda takes strategic resource allocations, patience, perseverance, focus, and rigorous evaluation.

\section{DISCUSSION}

At the outset of this research, the intent was to identify and analyze the engagement of policy-focused grantmaking foundations in the context of a policy engagement framework. The result was much richer and complex than what was anticipated, and thankfully so. From a theoretical perspective the framework has been modified (see Figure 2) not in content, as that was indeed verified, but in design, as it was discovered that these policy-focused grantmaking foundations are simultaneously engaged across and within multiple policy streams. Their engagement is both direct and indirect. They step to the forefront of the public policy arena to be counted and to exercise their experience, knowledge, and reputation. At the same time they act indirectly through grant recipients, acting not unlike venture capitalists that train and support the evolution of an enterprising start-up, or by providing substantive and sustainable grants to individuals and organizations that actively engage in the public policy process. Within policy streams they often engage at multiple levels and across multiple jurisdictions. For example, engagement can take place at a local, regional, and provincial level with civil society actors, intermediary organizations, and policymakers. 


\section{Figure 2: Modified policy engagement framework}

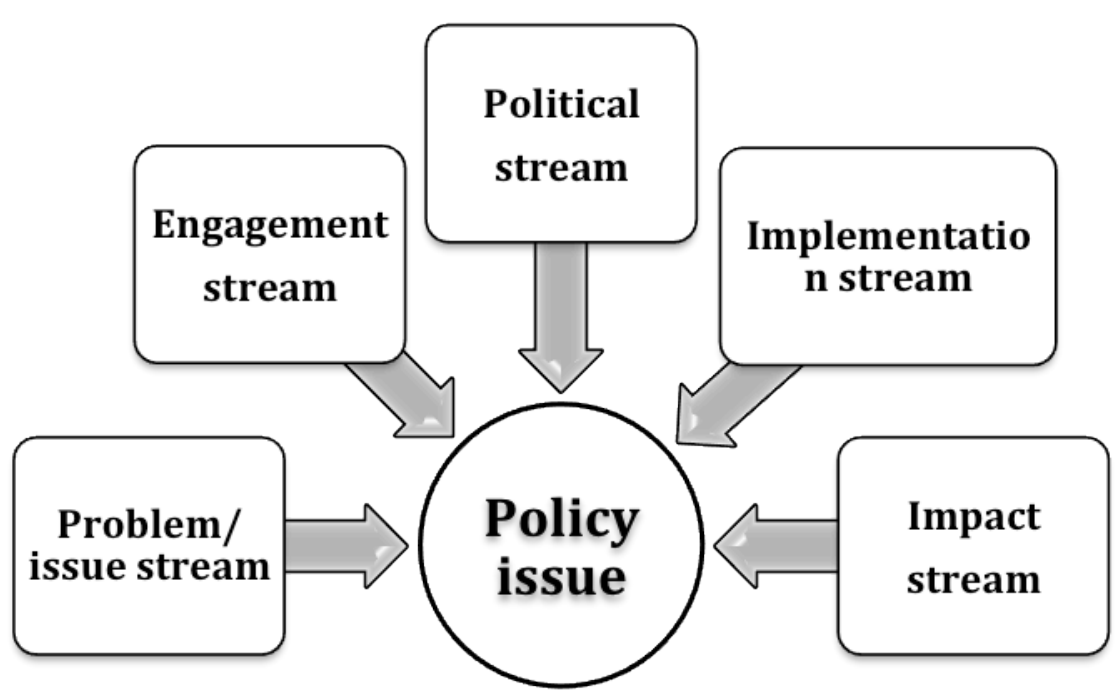

\section{Policy engagement framework}

The modified schematic (Figure 2) presents the range of policy interventions and process elements associated with public policy development and implementation. This revised framework, in our view, is a more accurate reflection of the nature of the engagement of policy-focused grantmaking foundations in public policy.

This study has focused on public policy engagement processes, rather than content. While some foundations were launched with a clear public policy mandate, most migrated into the public policy arena when they realized that it was either the best value for their investment of time and resources, or that their community program investments were being thwarted by public policies that hampered their full implementation.

\section{Policy engagement tools}

While there are a wide range of public policy engagement tools available to nonprofits, corporations, and charities alike (Coffman, 2008), these tools are often focused on their instrumental value to a particular public policy. This research revealed a number of policy engagement tools that we would associate with public policy system engagement. Funding, convening, and network building are clearly valuable and commonly used policy engagement tools and these foundations are no exception. However, they also include the following as public policy engagement tools: reputation, independence, legitimacy, quiet diplomacy, and collective advocacy.

\section{Policy system engagement}

The policy-focused grantmaking foundations studied here appreciate the interconnectedness of multiple systems. They are often working simultaneously at a municipal, regional, and a provincial level, particularly where a provincial policy may create a framework for action, but the real policy implementation occurs at a local level. If they are not engaging with these systems directly, they do so through their funding programs. This is where the high degree of policy focus becomes evident. They fund groups with the dedicated purpose of advancing a specific policy agenda, deliberately choosing organizations, or partners as some prefer to call them, that have the passion and capacity to engage in the public policy process. These organizations become long-term strategic partners rather than short-term fund recipients. Some foundations also establish a fund to 


\section{Elson \& Hall (2016)}

provide long-term support to individual policy entrepreneurs with a clear alignment to the foundations' policy agenda.

While there is a significant investment in public policy by these policy-focused grantmaking organizations, they are indeed unique, likely representing less than 0.5 percent of all foundations. There is also a preference to play a catalytic role in policy formulation, rather than replace the work of broader stakeholder groups that have a vested interest in policy outputs and impacts. All the foundations interviewed for this study were engaged in the problem/issue, policy, and political streams. Contrary to our initial expectation that foundations would focus their attention on the first two policy streams, what distinguishes these foundations from many others is their investment in political engagement and policy implementation.

There is an opportunity in the future to explore, in depth, the engagement of particular foundations in public policy process over multiple election cycles; to identify specific indicators of policy impact; and to conduct a comparative analysis of policy impact with multiple actors in the policy process.

\section{CONCLUSION}

The purpose of this article was to provide an analysis of how various policy-focused Canadian grantmaking foundations are engaged in different dimensions of the public policy process and to identify areas for future research. The policy-focused nature of their engagement in public policy was measured against independent recognition of their engagement, their sustained commitment to public policy engagement, and the significance of their investment of staff, social capital and financial resources.

This research provides an important insight into the complex systems associated with policy-focused grantmaking foundations and their engagement in public policy. While well recognized public policy engagement tools such as research, convening, funding, and coalition building were utilized by all these foundations, they were also prepared to put their reputation on the line; leverage their legitimacy, whether earned or awarded; engage in quiet diplomacy; and, where and when opportune, engage in collective advocacy. These policyfocused grantmaking foundations engage in public policy for the long-term, have the patience and perseverance to keep their eye on their policy objective while continually monitoring, assessing, and adjusting strategies as new information and opportunities come to light.

\section{ACKNOWLEDGEMENTS}

The authors would like to acknowledge funding for this research from the Social Sciences and Humanities Research Council of Canada Partnership Research Fund and the excellent feedback received from the anonymous reviewers. We would like to offer a special thanks to the foundations that generously gave their time to participate in the study.

\section{NOTES}

1. The word foundation is not restricted in Canada. Any organization can use the word foundation in its title. For example, a corporation could operate a foundation, but it could have no relationship to a public or private foundation as defined by Revenue Canada. For the purposes of this research only foundations designated as such by Revenue Canada will be studied. 


\section{Elson \& Hall (2016)}

2. The Canada Revenue Agency presumes that an activity is political if a charity explicitly communicates a call to political action (Canada Revenue Agency, 2003) (that is, encourages the public to contact an elected representative or public official and urges them to retain, oppose, or change the law, policy, or decision of any level of government in Canada or a foreign country) (Canada Revenue Agency, 2003).

3. The ten percent rule is the constraint that only up to ten percent of the total of a charity's financial assets, as well as everything the charity can use to further its purposes, such as its staff, volunteers, directors, and its premises and equipment, can be allocated to political activity.

4. Family and faith-based foundations are not legal terms. Family foundations are private foundations where the funds are derived from members of a single family (Council on Foundations, 2017). Faith-based foundations are private foundations where the funds are derived from a faith-based source.

\section{WEBSITES}

Atkinson Charitable Foundation, http://atkinsonfoundation.cal

Fondation Béati, http://www.fondationbeati.org/

Fondation Berthiaume-Du Tremblay, http://berthiaume-du-tremblay.com/

Fondation Dufresne et Gauthier, http://www.fdg.ca/en/

Fondation Solstice, http://www.fondationsolstice.org/

Foundation of the YMCAs of Québec, http://www.ymcaquebec.org/en/About-Us/Foundation-of-the-YMCAs-ofQuebec

J.W. McConnell Family Foundation, http://www.mcconnellfoundation.ca/en

Jimmy Pratt Foundation, http://jimmyprattfoundation.org/

Lawson Foundation, http://lawson.cal

Lea Roback Foundation, http://www.fondationlearoback.org/home.htm

Lucie et André Chagnon Foundation, http://fondationchagnon.org/en/index.aspx

Margaret \& Wallace McCain Family Foundation, http://mwmccain.ca/

Maytree Foundation, http://maytree.com/

Muttart Foundation, https://www.muttart.org/

Ontario Trillium Foundation, http://www.otf.ca/?redirected=1

Suncor Foundation Foundations, http://www.suncor.com/community-investment/suncor-energy-foundation Women's Y Foundation, http://fondation.ydesfemmesmtl.org/en/

\section{REFERENCES}

Alliance for Justice. (2004). Investing in change: A funders guide to supporting advoacy. Washington, DC: Alliance for Justice.

Anheier, H.K. (2005). Nonprofit organizations: Theory, management, policy. New York, NY: Routledge.

Barata, P., \& Murphy, C. (2011). Foundations for social change: Reflections on Ontario's poverty reduction strategy. Canadian Review of Social Policy, 65/66, 16-30.

Canada Revenue Agency. (2003). Political activities [CPS - 022] [Report]. Ottawa, ON: Charities Directorate, Canada Customs and Revenue Agency.

Canada Revenue Agency. (2016a). T3010 registered charity return. URL: http://www.craarc.gc.ca/E/pbg/tf/t3010/ [April 6, 2016].

Canada Revenue Agency. (2016b). Charities and giving glossary. URL: www.cra-arc.gc.ca/chrtsgvng/chrts/glssry-eng.html [April 6, 2016]. 


\section{Elson \& Hall (2016)}

Canada Revenue Agency. (2016c). Call to political action. URL: http://www.cra-arc.gc.ca/chrtsgvng/chrts/plcy/cps/cps-022-eng.html\#political [April 6, 2016].

Canada Revenue Agency. (2016d). What are political activities? URL: http://www.cra-arc.gc.ca/chrtsgvng/chrts/plcy/cps/cps-022-eng.html\#politicalactivities6-2 [April 6, 2016].

Carter, T.S., \& Man, T.L.M. (2010). Charities speaking out: The evolution of advocacy and political activities by charities in Canada.

Carter, T.S., \& Rains, L.E.C. (2015, February 26). Separating fact from fiction: Political activities revisited. Charity Law Bulletin, $361,8$.

Cave, J. (2016, February 29). The changing landscape for nonprofit policy advocacy. The Philanthropist. URL: http://thephilanthropist.ca/2016/02/the-changing-landscape-for-nonprofit-policy-advocacy/ [April 6, 2016].

Chase, S., \& Peritz, I. (2015). Thalidomide survivors to meet minister on day House votes on support. Globe \& Mail. URL: http://www.theglobeandmail.com/news/politics/thalidomide-survivors-to-meet-healthminister-house-to-vote-on-aid-next-week/article21819113/ [March 4, 2015].

Chatham House. (2016). Chatham House Rule. URL: https://www.chathamhouse.org/about/chatham-houserule\# [November 28, 2016].

Coffman, J. (2008). Foundations and public policy grantmaking. Los Angeles, CA: James Irvine Foundation. URL: http://www.mcf.org/system/article_resources/0000/0669/PublicPolicy_Coffman.pdf [April 6, 2016].

Council on Foundations. (2016). Family foundations. URL: http://www.cof.org/foundation-type/family-foundations [April 6, 2016].

Deakin, N. (2001). Putting narrow-mindedness out of countenance - the UK voluntary sector in the new millennium. In H.K. Anheier \& J. Kendall (Eds.), Third sector at the crossroads: An international nonprofit analysis (pp. 36-50). Book Section, London, UK: Routledge.

Frumkin, P. (2006). Accountability and legitimacy in American foundation philanthropy. In K. Prewitt, M. Dogan, S. Heyedemann, \& S. Toepler (Eds.), The legitimacy of philanthropic foundations: United States and European perspectives (pp. 99-122). New York, NY: Russell Sage Foundation.

Imagine Canada, \& Philanthropic Foundations Canada. (2014). Assets \& giving trends of Canada's grantmaking foundations. Toronto, ON: Imaging Canada. URL:

http://sectorsource.ca/sites/default/files/resources/files/trends-canadas-grantmaking-foundationssept2014.pdf [February 6, 2017].

Kendall, J. (2000). The mainstreaming of the third sector into public policy in England in the late 1900s: Whys and wherefores: Civil Society Working Paper 2 [Report]. London, UK: London School of Economics, Centre for Civil Society.

Kingdon, J.W. (1995). Agendas, alternatives, and public policies. New York, NY: Harper Collins College Publishers.

Lucie et André Chagnon Fondation. (2015a). Let's not lose sight of the impact of the reforms on social inequality. URL: http://www.fondationchagnon.org/en/news/2015/collectif_fondations_inegalites.aspx [January 30, 2017].

Lucie et André Chagnon Fondation. (2015b). Open letter: A smart investment in our future. URL: http://fondationchagnon.org/en/news/2015/looking_out_for_canada_and_for_our_children.aspx [January 30, 2017].

Mcllnay, D.P. (1998). How foundations work: What grantseekers need to know about the many faces of foundations. San Francisco, CA: Jossey-Bass.

Meehan, E.J. (1985). Policy: Constructing a definition. Policy Sciences, 18(4), 291-311.

Northcott, A. (2016, February 1). Charities have a moral obligation to help develop public policy. The Philanthropist. URL: http://thephilanthropist.ca/2016/02/charities-have-a-moral-obligation-to-help- [June 14, 2016]. 


\section{Elson \& Hall (2016)}

Philanthropic Foundations Canada. (2016). Foundations, charities and policy advocacy. URL: https://pfc.ca/2016/09/foundations-policy-advocacy/ [November 28, 2016].

Sabatier, P.A., \& Mazmanian, D.A. (1979). The conditions of effective implementation: A guide to accomplishing policy objectives. Policy Analysis, 5(Fall), 481-504.

Stacey, R.D. (1995). The science of complexity: An alternative perspective for strategic change processes. Strategic Management Journal, 16(6), 477-495. URL: http://doi.org/10.1016/0024-6301(95)99970-B [June 14, 2016].

Stacey, R.D. (2007). Strategic management and organizational dymanics: The challenge of compexity (5th ed.). London, UK: Pearson Education.

Turgeon, L. (2014). Activists, policy sedimentation, and policy change: The case of early childhoodeducation in Ontario. Journal of Canadian Studies, 48(2), 224-249.

Waddell, S., Waddock, S., Cornell, S., Dentoni, D., McLachlan, M., \& Meszoely, G. (2015). Large systems change: An emerging field of transformation and transitions. The Journal of Corporate Citizenship, 58(June), 5-30.

Westley, F., Zimmerman, B.J., \& Patton, M.Q. (2006). Getting to maybe: How the world is changed. Toronto, ON: Random House Canada.

Wheatley, M. (2006). Leadership and the new science: Discovering order in a chaotic world (3rd ed.). San Francisco, CA: Berrett-Koehler.

White, B. (2014). Charity calls for transparency in government "advocacy chill." URL: http://capitalnews.ca/politics-of-giving/charity-advocacy-chill/ [November 28, 2016].

Yin, R.K. (2009). Case study research: Design and methods (4th ed.). Thousand Oaks, CA: Sage.

\section{ABOUT THE AUTHORS / LES AUTEURS}

Peter R. Elson, PhD, is Senior Research Fellow in the Institute for Community Prosperity at Mount Royal University, 4825 Mount Royal Gate SW, Calgary, AB T3E 6K6, and Adjunct Assistant Professor, School of Public Administration at the University of Victoria, 3800 Finnerty Road, Victoria, BC V8P 5C2. Email: pelson@mtroyal.ca / pelson@uvic.ca .

Sara Hall is a PhD Candidate in the Department of Sociology at McGill University, 845 Sherbrooke Street W., Montreal, QC H3A 0G4, and is based in Vancouver, BC. Email: sara.hall@mail.mcgill.ca . 